6 Raviele A, Gasparini G, Di Pede F, Delise P, Bonso A, Piccolo E. Usefulness of head-up tilt test in evaluating patients with syncope of unknown origin and negative patients with syncope of unknown origin and negative

7 Raviele A, Gasparini G, Di Pede F, Menozzi C, Brignole $M$, Dinelli $M$, et al. Nitroglycerin infusion during upright tilt: a new test for the diagnosis of vasovagal syncope. $\mathrm{Am}$ Heart $\mathcal{~ 1 9 9 4 ; 1 2 7 : 1 0 3 - 1 1 . ~}$

8 Lurie KG, Dutton J, Mangat R, Newman D, Eisenberg S, Scheinman MM. Evaluation of edrophonium as a provocative agent for vasovagal syncope during head-up tilt-table testing. Am 7 Cardiol 1993;72:1286-90.

9 Grubb BP, Temesy-Armos P, Hahn H, Elliott L. Utility of tilt-table testing in th evaluation and management of syntilt-table testing in th evaluation and management

10 Pongiglione G, Fish FA, Strasburger JF, Benson DW Jr. Heart rate and blood pressure response to upright tilt in young patients with unexplained syncope. F $\mathrm{Am}$ Coll Cardiol 1990;16:165-70.

11 Kenny RA, Ingram A, Bayliss J, Sutton R. Head-up tilt: a useful test for the investigation of unexplained syncope. Lancet 1986;i:1352-4.

12 Fitzpatrick AP, Theodorakis G, Vardas P, Sutton R. Methodology of head-up tilt testing in patients with unexplained syncope. F Am Coll Cardiol 1991;17:125-30.

13 Kapoor WN, Brant N. Evaluation of syncope by upright tilt testing with isoproterenol. A nonspecific test. Ann Intern Med 1992;116:358-63.

14 Sheldon R. Evaluation of a single-stage isoproterenol-tilt table test in patients with syncope. F Am Coll Cardiol 1993;22:114-8.

15 Stevens PM. Cardiovascular dynamics during orthostasis and the influence of intravascular instrumentation. $A m \mathcal{F}$ Cardiol 1966;17:211-8.

\title{
Coronary ostial occlusion: "Have you seen anything like this?”
}

\author{
Iftikhar Ahmed, M C J Sissons, David Hesketh Roberts
}

A 48 year old deaf and dumb woman presented with a 12 month history that strongly suggested angina with recent worsening of chest pain. Diagnostic angiography showed normal coronary arteries. The procedure was uneventful but one hour later the patient suffered a fatal cardiorespiratory arrest. Postmortem examination revealed only that both coronary ostia were occluded by recent platelet rich antemortem thrombus in the absence of any underlying significant intimal disease or any evidence of trauma to the deeper tissues (figure). No primary site of embolisation was demonstrated. Stains for fungi and bacteria, autoimmune screening, and serology for syphilis were negative.

Any explanation to account for the pathology requires consideration of the cause of chest pain. This patient may have had an intense vasospastic potential and shut down her arteries over the catheters, thus allowing thrombus to develop. According to this hypothesis spasm would have been the cause of her prior angina. Alternatively she may have had an intense thrombotic potential which became manifest when the endothelium was damaged by catheters in the coronary orifices. This does not, however, explain the previous angina.

\section{Department of} Cardiology, Victoria Hospital, Blackpool I Ahmed

\section{Department of} Pathology, Victoria Hospital, Blackpool M C J Sissons

Department of Cardiology, Victoria Hospital, Blackpool D H Roberts

Correspondence to: Dr D H Roberts, Victoria Hospital, Whinney Heys Road, Blackpool, Lancashire FY3 8NR.

Accepted for publication 29 April 1996

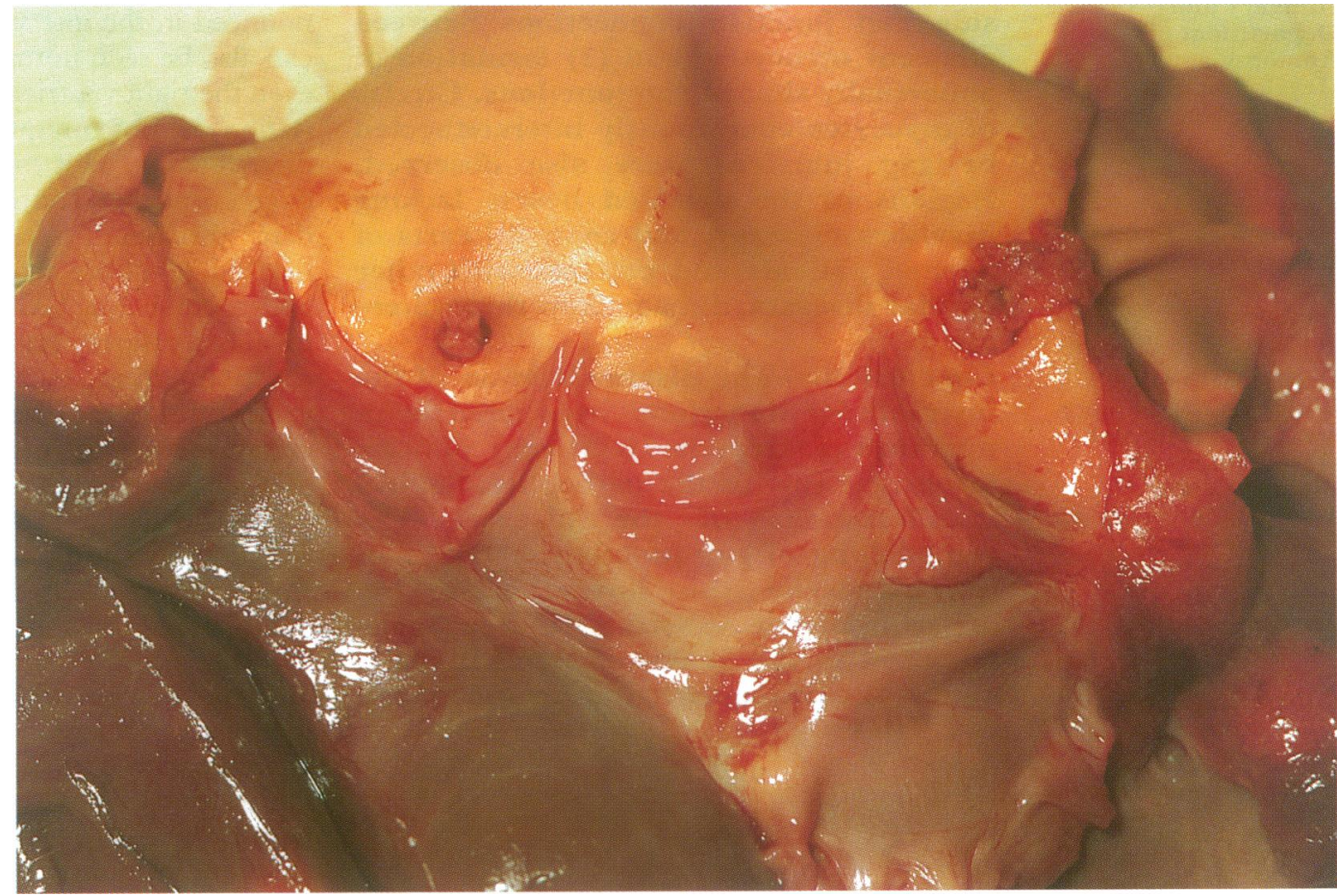

Anterior view of the ascending aorta showing thrombi at each coronary ostia. 